\title{
ISSR markers in wild species of Passiflora L. (Passifloraceae) as a tool for taxon selection in ornamental breeding
}

\author{
A.G.R. Sousa ${ }^{1}$, M.M. Souza ${ }^{1}$, C.A.F. Melo ${ }^{1}$ and G.A. Sodré ${ }^{2}$ \\ ${ }^{1}$ Departamento de Ciências Biológicas, Universidade Estadual de Santa Cruz, \\ Ilhéus, BA, Brasil \\ 2Departamento de Ciências Agrárias, Universidade Estadual de Santa Cruz, \\ Ilhéus, BA, Brasil \\ Corresponding author: M.M. Souza \\ E-mail: souzamagg@yahoo.com.br
}

Genet. Mol. Res. 14 (4): 18534-18545 (2015)

Received December 19, 2014

Accepted September 30, 2015

Published December 23, 2015

DOI http://dx.doi.org/10.4238/2015.December.23.41

\begin{abstract}
Inter simple sequence repeat (ISSR) molecular markers were developed and used to investigate interspecific genetic variation in 25 wild species of Passiflora preserved in an active germplasm bank (BAG-Passifloras); intraspecific diversity was also analyzed in $P$. cincinnata accessions. Of 31 primers tested, 20 identified polymorphic loci with a total of 331 bands, suggesting high polymorphism in the sample. Interspecific polymorphism was greater than intraspecific polymorphism. This is a common finding in studies of genetic variation using dominant markers. The ISSRs revealed species-specific amplification bands in 11 species; these bands ranged from 200 to $1000 \mathrm{bp}$, and they will be of use for developing SCAR markers for the identification of germplasm in further studies. The use of Jaccard's similarity coefficient to obtain a dendrogram by the UPGMA clustering method distributed the taxa into five major groups, with differences among grouping with respect to
\end{abstract}


principal coordinate analysis. Despite the high cophenetic correlation coefficient $(r=0.94)$ of the dendrogram, taxonomic inconsistencies were observed; similar irregularities have been reported previously in studies using dominant markers. Intraspecific analysis of $P$. cincinnata accessions revealed a larger genetic distance between those from Bahia (P2) and from Minas Gerais (P2), indicating that both accessions have considerable potential as parents in a genetic improvement program for this species.

Key words: Germplasm characterization; Molecular markers; Passion flower; Principal coordinate analysis

\section{INTRODUCTION}

The family Passifloraceae Juss. ex DC. is predominantly found in the tropical and subtropical areas of the Americas and Africa (Cervi and Imig, 2013), and consists of 17 genera and approximately 525 species. Brazil is the largest center of genetic diversity of the genus Passiflora L. and is also the center of origin of approximately 139 species (Bernacci et al., 2008). Numerically, Passiflora is the largest genus in the family with 83 endemic species that have been used as food, medicine, and also for ornamentation (Cervi et al., 2010). The considerable diversity within South America in terms of species largely accounts for this region being the main producer of passion fruit (Abreu et al., 2009). The Central North region of Brazil is regarded as the main center of the geographical distribution of Passiflora. However, anthropological activities have diminished the natural habitats of some species and, consequently, some taxa are now threatened (IAC, 2014). Moreover, in recent years, accessions of passion fruit vines in germplasm banks in Brazil, the United States, France, Australia, and elsewhere have notably declined (Faleiro et al., 2005). The conservation of this genetic resource for future germplasm characterization is important to enable the development of new lines in genetic breeding programs or in seedling rootstock production systems; germplasm conservation will also be vital to the diversification of production systems for new markets, such as for medicinal and ornamental plants. Because of their characteristics of exotic and beautiful flowers with strong and bright coloring and the fact that they bloom more than once per year, Passiflora species have been widely exploited as ornamental plants (Abreu et al., 2009). In the mid-18th century in Europe, interspecific crosses between $P$. racemosa Brot. and $P$. caerulea L. produced the first hybrids, Passiflora $\mathrm{x}$ violacea, for ornamental purposes (Vanderplank, 2000; Abreu et al., 2009). Currently, the interspecific hybrids of Passiflora represent a significant portion of the germplasm focused towards ornamentation (Abreu et al., 2009). Sexual hybridization in Passiflora is easily achieved between phylogenetically close species because of genetic compatibility and a low reproductive barrier (Abreu et al., 2009; Santos et al., 2012). In general, intraspecific hybridization can be an efficient method for obtaining improved plant lines because of increased hybrid vigor, especially in allogamous plants. For this reason, the use of molecular markers in the selection of parents can identify the optimal lines and, consequently, enable the generation of progeny with increased vigor and heterozygosity (Bueno et al., 2006; Borém and Miranda, 2005). Molecular markers have been used to identify genetic polymorphisms in population genetic studies, and are 
also of value for germplasm identification (Xi et al., 2008), characterizing genetic diversity (Sawadogo et al., 2009), protection of plant varieties (Isshiki et al., 2008), monitoring of crosses, and for the construction of genetic maps (Reddy et al., 2002). The various molecular markers differ in their relative abilities to detect polymorphism with respect to dominance and co-dominance, specificity, reproducibility, cost, and detection method (Collard and Mackill, 2009). The Inter Simple Sequence Repeat (ISSR) technique uses in vitro amplification of sequences located between microsatellites, and enables multi-locus genomic analysis with a single primer based on Simple Sequence Repeat (SSR) regions. ISSRs have been shown to be informative in studies on genetic diversity (Bornet and Branchard, 2001), phylogenetic and evolutionary relations (Reddy et al., 2002), and in the characterization of accessions and cultivars. These markers can therefore enable the identification of promising parental plants in genetic improvement programs (Isshiki et al., 2008). Unlike SSR molecular markers, ISSRs act as a dominant marker and do not require prior knowledge of the primer sequence. The ISSR technique also has good reproducibility, is easy to use, and has a low cost compared to other types of molecular marker, e.g., amplified fragment length polymorphisms and SSRs. The aim of this work was to develop ISSRs to study interspecific genetic diversity in 25 wild species of Passiflora preserved in the active Passiflora germplasm bank of the Universidade Estadual de Santa Cruz (UESC), and also to characterize intraspecific diversity in accessions of $P$. cincinnata Mast. The information obtained will identify germplasm resources for use in Passiflora improvement programs, such as through identification of wild species for producing hybrids with ornamental potential.

\section{MATERIAL AND METHODS}

Genomic DNA was extracted from 25 species of Passiflora and their respective accessions (Table 1) in the Passiflora germplasm bank of the UESC in Ilhéus, Bahia, Brazil. The protocol proposed by Doyle and Doyle (1990) was used to obtain the genomic DNAs. Young leaves were macerated in liquid nitrogen in a $2 \%$ CTAB conditioned buffer $(1.5 \mathrm{M} \mathrm{NaCl}, 20 \mathrm{mM}$ EDTA, $100 \mathrm{mM}$ Tris- $\mathrm{HCl}$, and $0.2 \% \beta$-mercaptoethanol) for $40 \mathrm{~min}$ at $65^{\circ} \mathrm{C}$. DNA was precipitated with chloroform:isoamyl alcohol (24:1) and then resuspended in TE buffer $(10 \mathrm{mM}$ Tris- $\mathrm{HCl}, 1 \mathrm{mM}$ EDTA). Genomic DNA concentrations were estimated by comparison with $100 \mathrm{ng}$ of lambda DNA (Promega, Wisconsin, United States) after electrophoresis on a 1.2\% agarose gel and stained with SYBR safe (Invitrogen). Each genomic DNA was diluted to $10 \mathrm{ng} / \mathrm{\mu L}$ in TE buffer.

The ISSR amplifications were performed using $31 \mathrm{UBC}$ ISSR primers (Table 2 ) in a reaction mixture containing $30 \mathrm{ng}$ genomic DNA solution, $10 \mathrm{mM}$ reaction buffer $10 \mathrm{mM} \mathrm{MgCl}{ }_{2}$ buffer, $5 \mu \mathrm{m}$ primer, $10 \mathrm{mM} \mathrm{dNTP}$, and $1 \mathrm{U}$ Taq DNA polymerase in a final volume of $20 \mu \mathrm{L}$. The amplifications were performed in a thermal cycler (Eppendorf Mastercycle) with the following schedule: initial denaturation at $95^{\circ} \mathrm{C}$ for $4 \mathrm{~min} ; 31$ cycles of denaturation for $30 \mathrm{~s}$ at $94^{\circ} \mathrm{C}$, annealing for $45 \mathrm{~s}$ at 50 $58^{\circ} \mathrm{C}$ depending on the primer (Table 2), extension for $2 \mathrm{~min}$ at $72^{\circ} \mathrm{C}$, and a final extension at $72^{\circ} \mathrm{C}$ for $10 \mathrm{~min}$. The amplified fragments in the ISSR reaction were stained with SYBR safe (Invitrogen) and separated by electrophoresis on a $1.8 \%$ agarose gel using $90 \mathrm{~V}$ for 50 minutes and $1 \mathrm{X} \mathrm{SB}$ buffer (100 $\mathrm{mM} \mathrm{H}_{3} \mathrm{BO}_{3}, 150 \mathrm{mM} \mathrm{NaOH}$ ).

The data were assembled into a binary matrix with reference to the presence (1) or absence (0) of bands. NTSYS-pc software 2.1 was used for the analysis of similarity between species and accessions, (Rohlf, 2000), and Jaccard's similarity coefficient was calculated 
(Jaccard, 1901). The unweighted pair group method with arithmetic mean (UPGMA) was used for dendrogram construction. The cophenetic correlation coefficient was calculated to compare the graphical representation against the original similarity matrix. Principal component analysis (PCO) was performed using NTSYS-pc software 2.1 (Rohlf, 2000) to group genotypes based on Jaccard's similarity coefficient (Jaccard, 1901). Corel DRAW X 5 (Corel) was used to produce the dendrogram and PCO graph.

Table 1. Species and accessions collected in Brazil and donated to other institutions, and preserved in the Passiflora active germplasm bank of the State University of Santa Cruz. Classification according to Ulmer and MacDougal (2004).

\begin{tabular}{|c|c|c|c|c|c|c|}
\hline Species & Subgenus & Supersection & Section & Series & Code & Accessions \\
\hline \multirow[t]{2}{*}{ P. maliformis $\mathrm{L}$. } & Passiflora & Laurifolia & - & Laurifoliae & 1 & 514 - P2 \\
\hline & & & & & 2 & $514-\mathrm{P} 1$ \\
\hline \multirow[t]{2}{*}{ P. filamentosa Cav. } & Passiflora & Passiflora & - & Passiflora & 3 & $513-P 1$ \\
\hline & & & & & 4 & $513-P 2$ \\
\hline P. malacophylla Mast. & Passiflora & - & - & - & 5 & 405 - P2 (Embrapa Cerrado) \\
\hline P. eichleriana Mast. & Passiflora & Stipulata & Granadillastrum & - & 6 & 488 - P1 (São Sebastião/RJ) \\
\hline \multirow[t]{2}{*}{ P. subrotunda Mast. } & Passiflora & Stipulata & Granadillastrum & - & 7 & 452 - P1 (Fortaleza/CE) \\
\hline & & & & & 8 & 452 - P2 (Fortaleza/CE) \\
\hline \multirow[t]{2}{*}{ P. actinia Hook } & Passiflora & Stipulata & Granadillastrum & - & 9 & 427 - P1 (UFPR) \\
\hline & & & & & 10 & 427 - P2 (UFPR) \\
\hline P. tenuifila Killip & Passiflora & Stipulata & Granadillastrum & - & 11 & 489 - P1 (Embrapa) \\
\hline P. foetida L. & Passiflora & Stipulata & Dysosmia & - & 12 & $490-\mathrm{P} 1$ \\
\hline P. vitifolia Kunth & Passiflora & Coccinea & - & - & 13 & 481 - P2 (Miranda/MG) \\
\hline \multirow[t]{2}{*}{ P. sublanceolata Killip } & Passiflora & Stipulata & Dysosmia & - & 14 & 496 - P2 (Embrapa) \\
\hline & & & & & 15 & 496 - P1 (Embrapa) \\
\hline \multirow[t]{2}{*}{ P. elegans Mast. } & Passiflora & Stipulata & Granadillastrum & - & 16 & 491 - P2 (Embrapa) \\
\hline & & & & & 17 & 491 - P1 (Embrapa) \\
\hline \multirow[t]{2}{*}{ P. racemosa Brot. } & Passiflora & Stipulata & Calopathanthus & - & 18 & $475-\mathrm{P} 1$ \\
\hline & & & & & 19 & 475 - P2 \\
\hline \multirow[t]{2}{*}{ P. misera $\mathrm{HBK}$} & Decaloba & Decaloba & Decaloba & - & 20 & $\mathrm{P} 1$ \\
\hline & & & & & 21 & P2 \\
\hline \multirow[t]{2}{*}{ P. hatschbachii Cervi } & Passiflora & Passiflora & - & Setaceae & 22 & $446-\mathrm{P} 1$ \\
\hline & & & & & 23 & $446-\mathrm{P} 2$ \\
\hline P. gibertii N.E. Brown & Passiflora & Stipulata & Granadillastrum & - & 24 & $\mathrm{P} 1$ \\
\hline \multirow[t]{2}{*}{ P. galbana Mast. } & Passiflora & Stipulata & Granadillastrum & - & 25 & $500-P 1$ \\
\hline & & & & & 26 & $500-P 2$ \\
\hline \multirow[t]{2}{*}{ P. suberosa L. } & Decaloba & Cieca & - & - & 27 & P2 (UENF) \\
\hline & & & & & 28 & P1 (UENF) \\
\hline P. trintae Sacco & Passiflora & - & - & - & 29 & $\mathrm{P} 1$ \\
\hline P. morifolia Mast. & Decaloba & Bryonioides & - & - & 30 & P2 (UENF) \\
\hline \multirow[t]{2}{*}{ P. serratodigitata L. } & Passiflora & Laurifolia & - & Tiliifolia & 31 & 487 - P2 (Embrapa Cerrado) \\
\hline & & & & & 32 & 487 - P1 (Embrapa Cerrado) \\
\hline \multirow[t]{3}{*}{ P. mucronata Lam. } & Passiflora & Stipulata & Granadillastrum & - & 33 & 509- P1 (Canavieiras/BA) \\
\hline & & & & & 34 & 508- P2 (UESC) \\
\hline & & & & & 35 & 508- P1 (UESC) \\
\hline \multirow[t]{2}{*}{ P. galbana Mast. } & Passiflora & & Granadillastrum & - & 36 & 507 - P2 (Oliveira/MG) \\
\hline & & & & & 37 & 507- P1 (Oliveira/MG) \\
\hline P. micropetala Mast. & Decaloba & Decaloba & Decaloba & - & 38 & $\mathrm{P} 1$ (IAC) \\
\hline \multirow[t]{2}{*}{ P. cerradensis Sacco } & Passiflora & Passiflora & - & Passiflora & 39 & 511 - P1 (Embrapa) \\
\hline & & Passiflora & & & 40 & 511 - P2 (Embrapa) \\
\hline \multirow[t]{8}{*}{ P. cincinnata Mast. } & Passiflora & & - & Passiflora & 41 & 504 - P2 (Bahia) \\
\hline & & & & & 42 & 504 - P1 (Bahia) \\
\hline & & & & & 43 & P1 (Campina de Moura /SP \\
\hline & & & & & 44 & P2 (Campina de Moura /SP \\
\hline & & & & & 45 & 503 - P1 (Instituto Plantarum) \\
\hline & & & & & 46 & 503 - P2 (Instituto Plantarum) \\
\hline & & & & & 47 & P1 (Minas Gerais) \\
\hline & & & & & 48 & P2 (Minas Gerais) \\
\hline
\end{tabular}

(P1) Plant 1; (P2) Plant 2. (EMBRAPA) Empresa Brasileira de Pesquisa Agropecuária; (UFPR) Universidade Federal do Paraná; (UENF) Universidade Estadual do Norte Fluminense Darcy Ribeiro; (IAC) Instituto Agronômico/Campinas, SP. 


\section{RESULTS}

Thirty-one ISSR primers were tested here and 20 (64\%) gave satisfactory amplification in the population under study (see Figure 1). The number of amplified bands ranged from eight for primer $(G A)_{8} Y C$ to 28 for primer $(C A)_{8} R C$, demonstrating a clear ability to detect polymorphisms (Table 2). A total of 331 ISSR bands were amplified, giving an average number of 16 bands per primer. Approximately $99 \%$ of the bands were polymorphic and 19 of the primers only amplified polymorphic bands; the exception was $(\mathrm{GT})_{8} \mathrm{~A}$ (UBC819) that amplified three monomorphic bands.

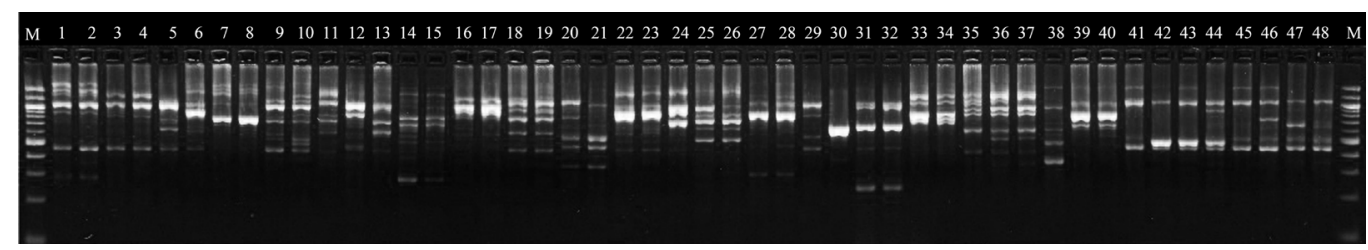

Figure 1. ISSR amplification products produced using the primer UBC826 and separated on a $1.8 \%$ agarose gel. (M) molecular weight marker 100 BP ladder, (1) Passiflora maliformis - P2; (2) P. maliformis - P1; (3) P. filamentosa - P1; (4) P. filamentosa - P2; (5) P. malacophylla - P2; (6) P. eichleriana - P1; (7) P. subrotunda - P1; (8) P. subrotunda P2; (9) P. actinia - P1; (10) P. actinia - P2; (11) P. tenuifila - P1; (12) P. foetida - P1; (13) P. vitifolia - P2; (14) P. sublanceolata - P2; (15) P. actinia - P1; (16) P. elegans - P2; (17) P. elegans - P1; (18) P. racemosa - P1; (19) P. racemosa - P2; (20) P. misera - P1; (21) P. misera - P2; (22) P. hatschbachii - P1; (23) P. hatschbachii - P2; (24) P. gibertii - P1; (25) P. galbana - P1; (26) P. galbana - P2; (27) P. suberosa - P2; (28) P. suberosa - P1; (29) P. trintae - P1; (30) P. morifolia - P2; (31) P. serratodigitata - P2; (32) P. serratodigitata - P1; (33) P. mucronata - P1; (34) P. mucronata - P2; (35) P. mucronata - P1; (36) P. galbana - P2; (37) P. galbana - P1; (38) P. micropetala - P1; (39) P. cerradensis - P1; (40) P. cerradensis - P2; (41) P. cincinnata (Bahia - P2); (42) P. cincinnata (Bahia - P1); (43) P. cincinnata (Campina de Moura - P1); (44) P. cincinnata (Campina de Moura - P2); (45) P. cincinnata (Instituto Plantarum - P1); (46) P. cincinnata (Instituto Plantarum - P2); (47) P. cincinnata (Minas Gerais - P1); (48) P. cincinnata (Minas Gerais - P2).

Table 2. ISSR primers used to study genetic diversity.

\begin{tabular}{|c|c|c|c|c|}
\hline Primer & Sequencies $\left(5^{\prime}-3^{\prime}\right)^{(1)}$ & $\mathrm{TM}\left({ }^{\circ} \mathrm{C}\right)$ & Total bands & No. poly. \\
\hline UBC 807 & AGAGAGAGAGAGAGAGT & 55.0 & 23 & 23 \\
\hline UBC 808 & AGAGAGAGAGAGAGAGC & 56.8 & 10 & 10 \\
\hline UBC 811 & GAGAGAGAGAGAGAGAC & 52.0 & 15 & 15 \\
\hline UBC 815 & СтстстстСтстстстG & 55.0 & 10 & 10 \\
\hline UBC 819 & GTGTGTGTGTGTGTGTA & 54.8 & 13 & 10 \\
\hline UBC 823 & ТСТСТСТСТСТСТСТСС & 55.0 & 20 & 20 \\
\hline UBC 825 & ACACACACACACACACT & 54.8 & 12 & 12 \\
\hline UBC 826 & ACACACACACACACACC & 57.2 & 20 & 20 \\
\hline UBC 828 & TGTGTGTGTGTGTGTGA & 54.8 & 10 & 10 \\
\hline UBC 834 & AGAGAGAGAGAGAGACYT & 55.0 & 19 & 19 \\
\hline UBC 835 & AGAGAGAGAGAGAGAGYC & 55.0 & 08 & 08 \\
\hline UBC 847 & CACACACACACACACARC & 58.8 & 28 & 28 \\
\hline UBC 850 & GTGTGTGTGTGTGTGTYC & 58.8 & 22 & 22 \\
\hline UBC 855 & ACACACACACACACACYT & 56.5 & 13 & 13 \\
\hline UBC 857 & ACACACACACACACACYG & 58.8 & 14 & 14 \\
\hline UBC 858 & TGTGTGTGTGTGTGTGRT & 56.5 & 15 & 15 \\
\hline UBC 861 & ACCACCACCACCACCACC & 64.5 & 20 & 20 \\
\hline UBC 868 & GAAGAAGAAGAAGAAGAA & 50.8 & 24 & 24 \\
\hline UBC 884 & HBHAGAGAGAGAGAGAG & 55.6 & 15 & 15 \\
\hline UBC 889 & DBDACACACACACACAC & 55.6 & 20 & 20 \\
\hline
\end{tabular}

(1) $D, Y$ and $V$ signify degenerate nucleotides: $D=(A, G, T) ; Y=(C, T)$; and $V=(A, C, G)$. TM, annealing temperature; total number of amplified bands per primer; No. poly., number of polymorphic bands per primer. 
Table 3. Species-specific bands exclusively generated by ISSR primers.

\begin{tabular}{lcc}
\hline Species & Primer (UBC) & Band (bp) \\
\hline Passiflora cerradensis & 884 & 910 \\
P. elegans & 850 & 260 \\
P. elegans & 857 & 420 \\
P. elegans & 884 & 310 \\
P. galbana & 868 & 510 \\
P. hatschbachii & 884 & 800 \\
P. maliformis & 807 & 900 \\
P. maliformis & 811 & 200 \\
P. maliformis & 826 & 950 \\
P. misera & 825 & 220 \\
P. misera & 826 & 320 \\
P. misera & 855 & 300 \\
P. morifolia & 811 & 1000 \\
P. serratodigitata & 847 & 780 \\
P. serratodigitata & 819 & 200 \\
P. serratodigitata & 858 & 210 \\
P. suberosa & 889 & 1000 \\
P. sublanceolata & 811 & 800 \\
P. sublanceolata & 826 & 270 \\
P. subrotunda & 828 & 700 \\
\hline
\end{tabular}

$\mathrm{bp}=$ base pair.

Analysis of $P$. cincinnata accessions, the species with the largest number of samples, yielded 134 ISSR bands: of these, 102 (76.11\%) were polymorphic. The presence of species-specific bands that were detectable in at least two accessions was observed for 11 species in the studied population (Table 3). Species-specific bands ranged from 200 to $1000 \mathrm{bp}$. $P$. elegans, $P$. maliformis, and $P$. misera showed the highest number of useful primers for the detection of species-specific bands, with three bands in each species.

The dendrogram produced using Jaccard's similarity coefficient and the UPGMA method identified five major groups (I, II, III, IV, and V) (Figure 2), with a high cophenetic correlation coefficient $(r=0.94)$. Group I could be subdivided into three subgroups, $A, B$, and $C$, although the latter only contained $P$. trintae. The closely related Group II had two subgroups, A and B. Group III had two subgroups, $A$ and $B$, the first containing two species, $P$. mucronata and $P$. galbana, and latter containing only $P$. micropetala. Group IV contained two subgroups, $\mathrm{A}$ and $\mathrm{B}$, the latter including two accessions of $P$. cerradensis. Group 5 was the least related to other groups, and contained only $P$. suberosa and $P$. morifolia.

The highest similarity coefficients were observed in the intraspecific analysis of $P$. subrotunda (0.8356), P. racemosa (0.8351), P. hatschbachii (0.8285), and $P$. filamentosa (0.8243). $P$. cincinnata accessions were found exclusively in Group IB (Figure 2). The similarity coefficients for $P$. cincinnata accessions revealed a greater genetic similarity between those from Bahia (0.6746), followed by those from Campina de Moura (0.6162) (Table 4). Less genetic similarity (0.4333) was observed in P. cincinnata accessions from Bahia (P2) and Minas Gerais (P2). P. mucronata accessions (P3) showed lower genetic similarity than did the other accessions of the same taxon (0.2637).

Jaccard's coefficient was used for the principal coordinate analysis (PCO) (Figure 3). In the PCO chart, two major groups could be distinguished, with one group exclusively containing the eight $P$. cincinnata accessions and other including the remaining species and accessions. 


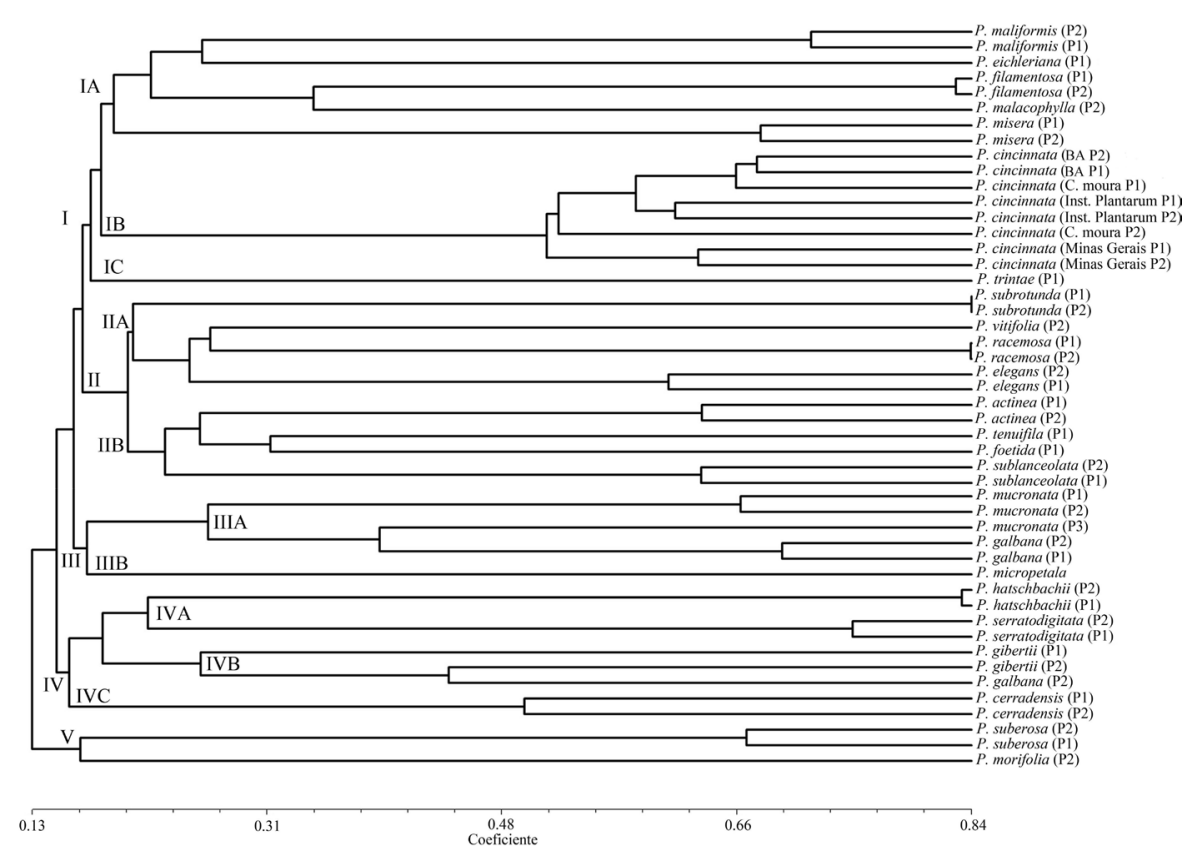

Figure 2. Dendrogram based on ISSR polymorphisms in species and accessions of Passiflora. The groups were generated using the UPGMA method with Jaccard's similarity coefficient. The value of the cophenetic correlation coefficient $(r)$ is 0.94 .

Table 4. Coefficients of genetic similarity between accessions of Passiflora cincinnata.

\begin{tabular}{|c|c|c|c|c|c|c|c|c|}
\hline Access & 41 & 42 & 43 & 44 & 45 & 46 & 47 & 48 \\
\hline 41 & 1.00000 & & & & & & & \\
\hline 42 & 0.67469 & 1.00000 & & & & & & \\
\hline 43 & 0.64772 & 0.67058 & 1.00000 & & & & & \\
\hline 44 & 0.47826 & 0.49438 & 0.61627 & 1.00000 & & & & \\
\hline 45 & 0.56666 & 0.55056 & 0.63636 & 0.53409 & 1.00000 & & & \\
\hline 46 & 0.55434 & 0.60919 & 0.58695 & 0.50549 & 0.61363 & 1.00000 & & \\
\hline 47 & 0.50000 & 0.59782 & 0.54545 & 0.50000 & 0.53608 & 0.62365 & 1.00000 & \\
\hline 48 & 0.43333 & 0.44827 & 0.51724 & 0.53750 & 0.50588 & 0.46067 & 0.63095 & 1.00000 \\
\hline
\end{tabular}

(41) Passiflora cincinnata (504 - Bahia) - Plant 2 (P2); (42) P. cincinnata (504 - Bahia) - P1; (43) P. cincinnata (Campina de Moura -Alegre/SP) - Plant 1 (P1); (44) P. cincinnata (Campina de Moura - Alegre/SP) - P2; (45) P. cincinnata (503 - Instituto Plantarum) - P1; (46) P. cincinnata (503 - Instituto Plantarum) - P2; (47) P. cincinnata (Minas Gerais) - P1; (48) P. cincinnata (Minas Gerais) - P2.

\section{DISCUSSION}

The development of ISSR molecular markers in agronomically important crops such as tomato (Tikunov et al., 2003), eggplant (Isshiki et al., 2008), and passion fruit (Santos et al., 2011) provided important insights into intraspecific genetic diversity; this information has proved invaluable for the use of these genetic resources in conservation and for genetic improvement. Although the use of ISSR markers is widespread in plants, relatively little has been reported in passifloras, except for wild species (Santos et al., 2011). However, genetic diversity in Passiflora 


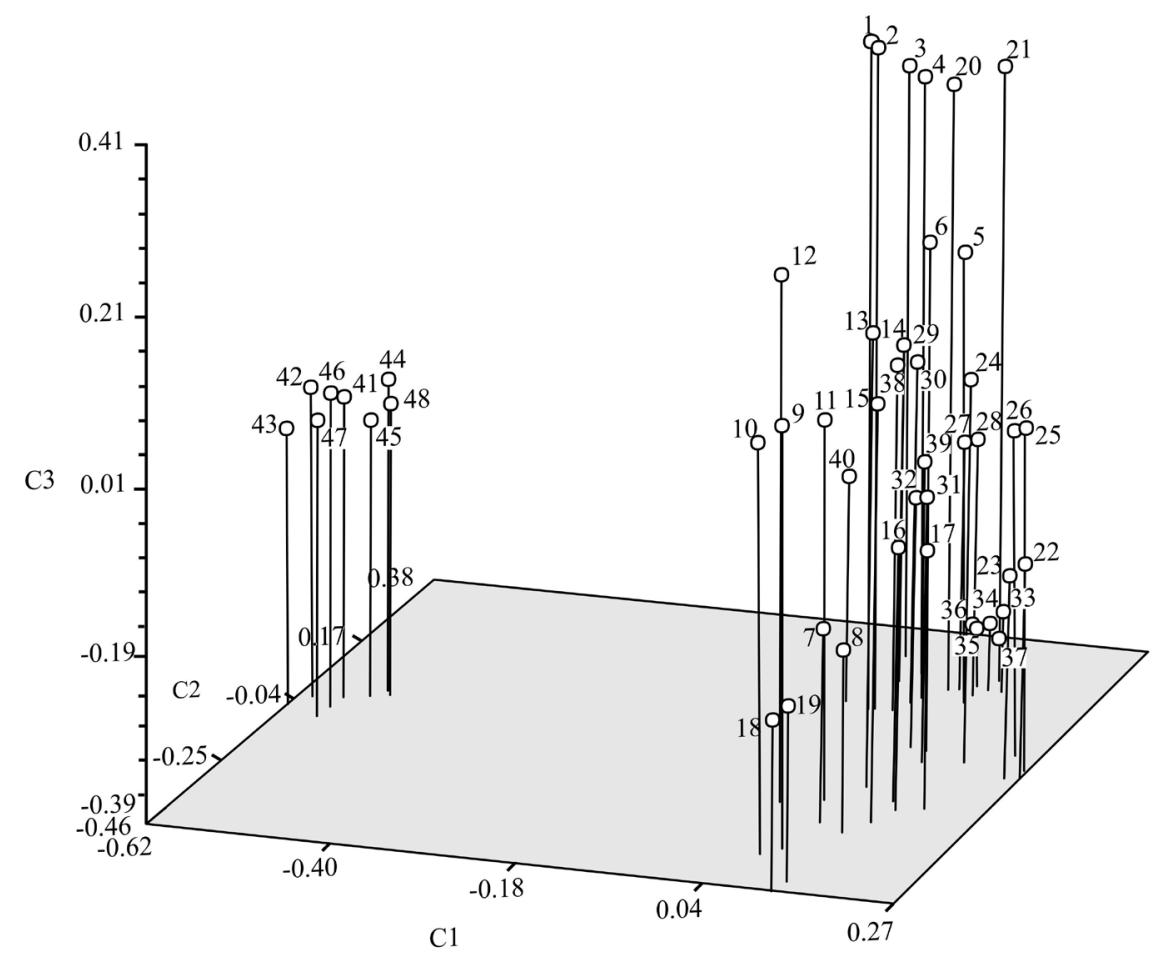

Figure 3. Principal component analysis of species of the genus Passiflora based on the Jaccard's similarity coefficient. The numbers on the chart show the species and accessions shown in Figure 1.

has been investigated using other dominant markers, such as AFLPs (Ganga et al., 2004) and random amplified polymorphic DNA (RAPD) markers (Fajardo et al., 1998), and co-dominant markers such as SSRs (Pádua et al., 2005; Oliveira et al., 2008; Silva et al., 2014). In the present study, genetic diversity was analyzed with 20 ISSR markers; most of the amplification primers were based on dinucleotides, suggesting a high rate of dinucleotide SSR repeats in the genus Passiflora. However, the genome of $P$. edulis contains many trinucleotide SSR repeats as evidenced by the amplification of ISSR primers based on trinucleotide sequences in commercial accessions (Santos et al., 2011). In general, the presence of SSR dinucleotides is the most common repeat in the genome of plants, such as in Arabidopsis thaliana, which has abundant dinucleotide sequences in the coding regions (Casacuberta et al., 2000).

Here, the presence of unique ISSR alleles in the Passiflora species was verified through the existence of species-specific bands. Unique bands amplified by ISSR primers have applications in both germplasm identification and genetic improvement programs (Isshiki et al., 2008; Lee et al., 2011). Additionally, species-specific bands and accession or cultivar restricted bands can be transformed into SCAR (sequenced characterized amplified region) type markers to increase specificity and reproducibility. In cultivars of medicinal Panax ginseng, the development of SCAR markers based on ISSR regions has enabled the differentiation of one of the six analyzed cultivars (Lee et al., 2011). In the present study, the species-specific bands could be used for confirmation of interspecific crosses or for germplasm protection. 
By contrast to previous genetic diversity studies in Passiflora, the estimation of genomic variation was performed using a large number (331) of polymorphic loci (Santos et al., 2011). Generally speaking, the use of random primers in an interspecific analysis identifies a higher number of polymorphic bands in comparison to an intraspecific analysis (Fajardo et al., 1998; Santos et al., 2011). In agreement with this expectation, we observed greater interspecific polymorphism (99\%) than intraspecific polymorphism (76\%) in Passiflora. An intraspecific analysis performed using RAPD markers reported an average of $63.8 \%$ polymorphism in P. nitida (Ganga et al., 2004) and in $P$. setacae (Cerqueira-Silva et al., 2012). However, an intraspecific analysis with ISSR markers found higher polymorphism $(98 \%)$ in $P$. alata (Santos et al., 2011). In interspecific analyses, a higher rate of polymorphism in combination with an increased average number of amplified bands per primer is indicative of high genetic variability (Cerqueira-Silva et al., 2012). Nevertheless, high intraspecific genetic variability was also observed here among the eight $P$. cincinnata accessions.

Although the high cophenetic correlation coefficient $(r=0.94)$ suggested fidelity of the graphical representation in the dendrogram, some taxa were distributed without taxonomic support. Thus, species of the same series were separated into different groups, for example, $P$. misera and $P$. micropetala, which both belong to the subgenus Decaloba and the Decaloba section $(2 n=12)$ were positioned in the distinct groups I and III, respectively. By contrast, $P$. foetida and $P$. sublanceolata, which belong to the subgenus Passiflora, Dysosmia Section, were positioned consistently with regard to their taxonomic category $(2 n=22)$ and in Group III. The study of genetic diversity in species of the genus Passiflora using RAPD markers distributed the taxa preferentially according to subgenus and section, indicating that these markers were a useful tool for taxonomic and phylogenetic studies; however, some species of the subgenus Passiflora and Decaloba did not show the expected relationship on their dendrogram (Fajardo et al., 1998). The species of Group V, P. suberosa and $P$. morifolia, showed greater diversity than other taxa; these were the only representatives of the subgenus Decaloba, from the Cieca supersection and Bryonioides, respectively. Fajardo et al. (1998) reported that Passiflora coriacea, from the Supersection Cieca, showed more dissimilarity than other species analyzed with RAPD markers. This conclusion reinforces the great distinction between RAPD and ISSR loci in taxa of the Cieca section compared to other botanical sections of this genus.

In this study, Jaccard's similarity coefficient and the UPGMA clustering method was used for verification of genetic diversity. Additional analyses using the Simple Matching similarity coefficient and S-Dice were also performed with the intention of decreasing collation errors based on phylogenetic and taxonomic relationships. In Passiflora, the test anticipated various similarity coefficients and was a strategy to minimize collation errors in relation to the taxonomy, making it possible to choose the most suitable method for the sample group (Fajardo et al., 1998; Crochemore et al., 2003; Viana et al., 2003). However, the choice of similarity or dissimilarity coefficients needs to be adequate for the studied population and for the particular marker used (Murguía and Villaseñor, 2003). The representation of genetic diversity in the PCO graph differed considerably among $P$. cincinnata accessions than in other species, in contrast to the dendrogram obtained by UPGMA grouping; this result indicated that $P$. cincinnata accessions were exclusively positioned in Group II. The PCO chart enabled the differentiation of the largest number of intraspecific taxon comparisons (eight accessions of $P$. cincinnata) from the other species examined. The differences observed in the two grouping methods indicates that principal coordinate analysis can generate a distancing of taxa that are classified as being closely related in UPGMA grouping (Silva et al., 2011).

The analysis of intraspecific diversity among the eight $P$. cincinnata accessions revealed 
genetic dissimilarity among plants within the same accession, confirming their origin by crosses and not as clones. The least genetic similarity was observed between the $P$. cincinnata accessions from Bahia (P2) and Minas Gerais (P2), indicating that both accessions are potential progenitors for use in intraspecific interbreeding.

Heterosis, a hallmark of passifloras, is a result of the low self-incompatibility among species of the genus and can be exploited through crosses between heterozygous parents (Lippman and Zamir, 2007). Generally, $F_{1}$ hybrids exhibit superior heterosis than the parental species, resulting in better adaptation and an increased fitness in comparison to their parents. However, in just a few generations of crosses and backcrosses the high heterosis and its beneficial effects may be lost (Lippman and Zamir, 2007; Sanghera et al., 2011). Heterosis is characteristic of interspecific hybrids and the results in this study will be useful in selection of promising parents for conducting interspecific crosses. Thus, we suggest that species with lower levels of genetic similarity, as determined by their ISSR markers, could be used as parental plants in breeding programs for hybrid production.

Despite the weak reproductive barriers between species of the Passiflora genus, the artificial production of hybrids has only been reported for species that share the same diploid chromosome number; thus, this is an essential feature for the selection of genitors for hybridization (Conceição et al., 2011; Santos et al., 2012). Choice of parents for crosses can be made between taxa assigned to distinct groups by UPGMA clustering (dendrogram) to obtain progeny with higher fitness, for example, between $P$. filamentosa (group I) $\times P$. suberosa (group V), which have $2 n=$ 18 , or $P$. misera (group I) $\times P$. micropetala (group III), which have $2 \mathrm{n}=12$. Although it is possible to select parents within the same group, they would preferably be from different subgroups, for example, $P$. subrotunda (Group IIA) x P. actinea (Group IIB). However, the selection of parents to obtain hybrids with ornamental potential should be carried out with the inclusion of data on floral characteristics, such as color and flower size and also period and duration of anthesis. Thus, in addition to use of molecular parameters for genitor selection, phenotypic characteristics can also be important to obtain progeny suitable for the ornamental flower market.

\section{Conflicts of interest}

The authors declare no conflict of interest.

\section{ACKNOWLEDGMENTS}

We thank UESC, CNPq (Conselho Nacional de Desenvolvimento Científico e Tecnológico) and FAPESB (Fundação de Amparo à Pesquisa do Estado da Bahia) for the financial support for research; CAPES (Coordenação de Aperfeiçoamento de Pessoal de Nível Superior) for the scholarships granted to the first author; CNPq for the scholarship awarded to the second author.

\section{REFERENCES}

\footnotetext{
Abreu PP, Souza MM, Santos EA, Pires MV, et al. (2009). Passion flower hybrids and their use in the ornamental plant market: perspectives for sustainable development with emphasis on Brazil. Euphytica 166: 307-315.

Bernacci LC, Soares-Scott MD, Junqueira NTV, Passos IRS, et al. (2008). Passiflora edulis Sims: the correct taxonomic way to cite the yellow passion fruit (and of others colors). Rev. Bras. Frutic. 30: 566-576.

Borém A and Miranda GV (2005). Melhoramento de Plantas. 4. ed. UFV, Viçosa.
} 
Bornet B and Branchard M (2001). Nonanchored inter simple sequence repeat (ISSR) markers: reproducible and specific tool for genome fingerprinting. Plant Mol. Biol. Rep. 19: 209-215

Bueno LCS, Mendes ANG and Carvalho SP (2006). Melhoramento de plantas: princípios e procedimentos. UFLA, Lavras.

Casacuberta E, Puigdomenech P and Monfort A (2000). Distribution of microsatellites in relation to coding sequences within the Arabidopsis thaliana genome. Plant Sci. 157: 97-104.

Cerqueira-Silva CBM, Santos ESL, Conceição LDHCS, Cardoso-Silva CB, et al. (2012). Genetic variation in a wild population of the 'sleep' passion fruit (Passiflora setacea) based on molecular markers. Genet. Mol. Res. 11: 731-738.

Cervi AC and Imig DC (2013). A new species of Passiflora (Passifloraceae) from Mato Grosso do Sul, Brazil. Phytotaxa 103: 46-50.

Cervi AC, Azevedo MAM and Bernacci LC (2010) Passifloraceae. In: Catálogo de plantas e fungos do Brasil. (Forzza RF, et al., ed.). Jardim Botânico do Rio de Janeiro, Rio de Janeiro, 2: 1432-1436.

Collard BCY and Mackill DJ (2009). Conserved DNA-derived polymorphism (CDDP): a simple and novel method for generating DNA markers in plants. Plant Mol. Biol. Rep. 27: 558-562.

Conceição LDHCS, Souza MM, Belo GO, Santos S, et al. (2011). Hybridization among wild passionflower species. Rev. Bras. Bot. 34: 237-240.

Crochemore ML, Molinari HBCand Vieira LGE (2003). Genetic diversity in passion fruit (Passiflora spp.) evaluated by RAPD markers. Braz. Arch. Biol. Technol. 46: 521-527.

Doyle JJ and Doyle JL (1990). Isolation of plant DNA from fresh tissue. Focus 12: 13-15.

Fajardo D, Angel F, Grum M, Tohme J, et al. (1998). Genetic variation analysis of the genus Passiflora L. using RAPD markers. Euphytica 101: 341-347.

Faleiro FG, Junqueira NTV, Braga MF and Peixoto JR (2005). Germoplasma e melhoramento genético do maracujazeiro Desafios da pesquisa. In: Maracujá: germoplasma e melhoramento genético (Faleiro FG, Junqueira NTV and Braga MF, eds.). Embrapa Cerrados, Planaltina, 187-209.

Ganga RMD, Ruggiero C, Lemos EGM, Grili GVG, et al. (2004). Diversidade genética em maracujazeiro-amarelo utilizando marcadores moleculares fAFLP. Rev. Bras. Frutic 26: 494-498.

Herbário Instituto Agronômico - IAC (2014). Available at [http://herbario.iac.sp.gov.br]. Accessed July 31, 2014.

Isshiki S, Iwata N and Khan MMR (2008). ISSR variations in eggplant (Solanum melongena L.) and related Solanum species. Sci. Hortic. 117: 186-190.

Jaccard P (1901). Étude comparative de la distribution florale dans une portion des Alpes et des Jura. Bull. Soc. Vaudoise Sci. Nat. 37: 547-579.

Lee JW, Kim YC, Jo IH, Seo AY, et al. (2011). Development of an ISSR-derived SCAR marker in Korean ginseng cultivars (Panax ginseng C. A. Meyer). J. Ginseng Res. 35: 52-59.

Lippman ZB and Zamir D (2007). Heterosis: revisiting the magic. Trends Genet. 23: 60-66.

Murguía M and Villaseñor M (2003). Estimating the effect of the similarity coefficient and the cluster algorithm on biogeographic classifications. Ann. Bot. Fennici. 40: 415-421.

Oliveira EJ, Vieira MLC, Garcia AAF, Munhoz CF, et al. (2008). An integrated molecular map of yellow passion fruit based on simultaneous maximum-likelihood estimation of linkage and linkage phases. J. Am. Soc. Hortic. Sci. 133: 35-41.

Pádua JG, Oliveira EJ, Zucchi MI, Oliveira GCX, et al. (2005). Isolation and characterization of microsatellite markers from the sweet passion fruit (Passiflora alata Curtis: Passifloraceae). Mol. Ecol. Notes 5: 863-865.

Reddy PM, Sarla N and Siddiq EA (2002). Inter simple sequence repeat (ISSR) polymorphism and its application in plant breeding. Euphytica. 128: 9-17.

Rohlf FJ (2000). NTSYS-pc: numerical taxonomy and multivariate analysis system, version 2.1. New York: Exeter Software 83.

Sawadogo M, Ouedraogo JT, Balma D, Ouedraogo M, et al. (2009). The use of cross species SSR primers to study genetic diversity of okra from Burkina Faso. Afr. J. Biotechnol. 11: 2476-2482.

Santos LF, Oliveira EJ, Santos AS, Carvalho FM, et al. (2011). ISSR markers as a tool for the assessment of genetic diversity in Passiflora. Biochem. Genet. 49: 540-554

Santos EA, Souza MM, Abreu PP, Conceição LDHCS, et al. (2012). Confirmation and characterization of interspecific hybrids of Passiflora L. (Passifloraceae) for ornamental use. Euphytica 184: 389-399.

Sanghera GS, Wani SH, Hussain WS, Wajida HA, et al. (2011) The magic of heterosis: new tools and complexities. Nat. Sci. 9: 42-53.

Silva KVP, Alves AAC, Martins MIG, Melo CAF, et al. (2011). Variabilidade genética entre acessos do gênero Manihot por meio de marcadores moleculares ISSR. Pesq. Agropec. Bras. 46: 1082-1088.

Silva MAA, Souza MM, Silva GS, Melo CAF, et al. (2014). Analysis of transferability of microsatellite primers (SSR) in wild Passiflora species and intraspecific genetic diversity in Passiflora alata. Genet. Mol. Res. 13: 5908-5918.

Tikunov YM, Khrustaleva LI and Karlov G (2003). Application of ISSR markers in the genus Lycopersicon. Euphytica 131: 71-81. 
Vanderplank J (2000) Passion flowers. The MIT Press, Cambridge.

Viana AP, Pereira TNS, Pereira MG, Souza MM, et al. (2003). Diversidade genética entre genótipos comerciais de Maracujazeiro-Amarelo (Passiflora edulis f. flavicarpa) e entre espécies de passifloras nativas determinadas por marcadores RAPD. Rev. Bras. Frutic. 25: 489-493.

Xi ZY, He FH, Zeng RZ, Zhang ZM, et al. (2008). Characterization of donor genome contents of backcross progenies detected by SSR markers in rice. Euphytica 160: 369-377. 